\title{
Adsorption of Vanadium(V) From Textile Industry Effluent Using Luffa cylindrica Activated Carbon
}

\author{
K. Nwosu-Obieogu, G. Dzarma, B. Okolo, K. Akatobi, and F. Aguele
}

Chemical Engineering Department, Michael Okpara University of Agriculture,

Umuahia, Abia State, Nigeria

\begin{abstract}
This study investigated the utilisation of Luffa cylindrica activated carbon as a low-cost adsorbent in the removal of vanadium(V) from textile industry effluent in a batch adsorption experiment. The adsorption rate was studied for contact time, $\mathrm{pH}$, and adsorbent dosage. The effect of $\mathrm{pH}$ on vanadium $(\mathrm{V})$ removal was studied with $0.2 \mathrm{~g} / 100 \mathrm{ml}$ adsorbent dose, $10 \mathrm{~min}$ contact time, and textile effluent solution. The maximum removal efficiency was $99.90 \%$ at pH 4, 97.43\% at 60 min of contact time, and $97.83 \%$ at an adsorbent dosage of $1.0 \mathrm{~g}$. The characterisation results from FTIR and SEM indicated that the adsorbents' potential was fully exploited. In this study, the experimental findings were fitted using Langmuir and Freundlich isotherm models. Freundlich model gave a better fit of the experimental data. The kinetic data by the pseudo-second order kinetic model gave a better fit than the pseudo-first order kinetic model.
\end{abstract}

Keywords

Adsorption, Luffa cylindrica, efficiency, textile industry effluent, environment

\section{Introduction}

Over the years, increased industrial activities have adversely affected the environment. These continuously increasing anthropogenic activities directly relate to the observed increase in pollution of various forms. Notable among these forms of environmental pollution is the type caused by the release of poisonous heavy metals. ${ }^{1}$ The interaction of the released heavy metals ions in the environment and their toxic levels is a function of their various redox potentials and aqueous speciation. Metal ions constitute a major category of water contaminants and these toxic ions enter the environment from various industrial processes such as paint, mining, cement industries, and many more. Outrageous levels of heavy metal get discharged in the environment through the release of untreated industrial liquid waste leading to pollution of ground and open water bodies. Toxic metals such as vanadium (V), arsenic (As), chromium $(\mathrm{Cr})$, lead $(\mathrm{Pb})$, cadmium $(\mathrm{Cd})$, copper $(\mathrm{Cu})$, mercury $(\mathrm{Hg})$, zinc $(\mathrm{Zn})$, nickel $(\mathrm{Ni})$, and silver $(\mathrm{Ag})$ have been identified to have a significant effect on human health, animals, and plants. The hazard posed by these heavy metals is attributed to their tendencies to bio-accumulate in systems, and their non-biodegradability. ${ }^{2,3}$

Vanadium $(\mathrm{V})$, being a rare metal, occurs naturally in earth mineral formations, its average concentration in the Earth's crust is $150 \mathrm{mg} \mathrm{dm}^{-3}$, and is very soluble in water, making it an active source of water pollution when not controlled during discharge of process effluents. Vanadium(V) ingested into human systems in amounts above safe limits causes several health issues, ranging from respiratory, cardiac, digestive, and nervous system problems to skin irritation problems. It is believed that below $1 \mathrm{mg} \mathrm{dm}^{-3}$ (24 h) en-

* Corresponding authors: Kenechi Nwosu-Obieogu, M. Eng.

Email: kenenwosuobie@gmail.com vironmental exposure to vanadium $(\mathrm{V})$ is not likely to have adverse effects on human health. For this reason, finding effective ways to reduce the level of vanadium(V) in textile effluents to acceptable limits before discharging them into the environment is of paramount significance. ${ }^{4}$

Over time, several conventional approaches, such as chemical precipitation, electrolysis, solvent extraction, ion exchange, membrane filtration, and reverse osmosis have been utilised in the removal of heavy metals from wastewater. However, these techniques have issues that limit their application, which include high execution costs, low removal efficiency, incomplete removal, and production of large toxic waste slurries. ${ }^{5} \mathrm{~A}$ more suitable approach used in the removal of heavy metals from wastewater employs the use of bio-based adsorbents and activated carbon produced from agricultural waste products. These bio-materials have advantages of low cost, high selectivity, good adsorption capacity, biodegradability and recyclability, and waste utilisation, which help in curtailing pollution. ${ }^{6}$

Adsorption of heavy metals from wastewater using activated carbon from several agricultural by-products has been reported, such as removal of hexavalent chromium $\mathrm{Cr}(\mathrm{VI})$ using different natural adsorbents, ${ }^{7}$ kinetics, mechanism, and equilibrium studies on removal of lead(II) using citrus limettioides peel and seed carbon, ${ }^{8}$ removal of $\mathrm{Pb}$ (II) ions from aqueous media using peanut shell biochar, ${ }^{9}$ and more. The experimental findings have revealed the attractiveness of this adsorption technique.

Luffa cylindrica is abundantly found across Asia (India, Korea, China, and Japan), Latin America, and Africa (Nigeria). It belongs to the family Cucurbitaceae, it is a non-edible plant and mainly lignocellulose in nature $(60 \%$ cellulose, $30 \%$ hemicellulose, and $10 \%$ lignin by weight). It is composed of a fibro-vascular stem, very biodegradable and recyclable, making it a suitable adsorbent choice. ${ }^{10,11}$ Oboh 
reported on the physical properties of Luffa cylindrica adsorbent; its specific surface area (BET) $\left(\mathrm{m}^{2} \mathrm{~g}^{-1}\right)$, total surface area $\left(\mathrm{m}^{2} \mathrm{~g}^{-1}\right)$, pore diameter range and bulk density $\left(\mathrm{g} \mathrm{cm}^{-3}\right)$ were determined as 0.28, 1.1895, 1051.309204 to 0.003577 , and 0.34 , respectively, and it signified that its surface area is low, with pore diameter and bulk density values in concordance with those found in typical mesoporous materials. ${ }^{12}$ This paper studies the removal of vanadium(V) from textile industry effluent using activated carbon developed from Luffa cylindrica.

\section{Materials and methods}

The raw effluent was collected from a textile factory in Osisioma, Aba, Abia state. Luffa cylindrica was collected from nearby bushes and incomplete buildings in Ikwuano area, Abia, Nigeria. The sponge was separated from the bark, and the seeds removed, the sponge washed with distilled water to remove dust particles, and then dried at $100{ }^{\circ} \mathrm{C}$ for $24 \mathrm{~h}$. The dried sponge was then crushed and ground into small particles, washed with distilled water to remove traces of absorbed salts, treated with $\mathrm{NaOH}(60 \%)$, and carbonised in a muffle furnace for $4 \mathrm{~h}$ at a temperature of $700{ }^{\circ} \mathrm{C}$. The furnace was then cooled to room temperature, and the obtained product was washed with distilled water until the $\mathrm{pH}$ of the filtrate was neutral. It was then dried at $100{ }^{\circ} \mathrm{C}$, and sieved using a particle size of $0.5 \mathrm{~mm}$ to obtain a fine powder of activated carbon.

\subsection{Adsorbent characterisation}

\subsubsection{FTIR analysis}

The Fourier transform infrared (FTIR) analysis of the sample was carried out to find the functional groups present on the surface of the absorbent using the FTIR spectrometer (PerkinElmer Spectrum one v3.02 Spectrometer, India).

\subsubsection{Scanning electron microscope (SEM) analysis}

Scanning electron microscope (Hitachi S-5500, Japan) was used to determine the morphological structure of the LAC before and after adsorption.

\subsection{Textile effluent characterisation}

The effluent was analysed for the presence of heavy metals by digesting $100 \mathrm{ml}$ of the effluent using $10 \mathrm{ml}$ of $70 \%$ $\mathrm{H}_{2} \mathrm{SO}_{4}$ in a $250 \mathrm{ml}$ conical flask placed in a fume cupboard. The concentrations of the heavy metals in the wastewater were determined using atomic absorption spectrometer (MODEL: AA-7000, Shimadzu, Japan).

\subsection{Batch adsorption studies}

The initial $\mathrm{pH}$ of the textile effluent sample was taken using a $\mathrm{pH}$ meter (pH-2601) and $100 \mathrm{ml}$ of the effluent was transferred to a $250 \mathrm{ml}$ Erlenmeyer flasks. An amount of $0.2 \mathrm{~g}$ of Luffa cylindrica activated carbon (LAC) was weighed using an electronic balance, and added to the effluent. The solution was agitated for $10 \mathrm{~min}$ using a speed adjusting multipurpose vibrator at $100 \mathrm{rpm}$, after which $10 \mathrm{~cm}^{3}$ of the solution was further centrifuged for $5 \mathrm{~min}$ before taking a spectrophotometer reading. Effects of adsorption parameters were studied. The effect of $\mathrm{pH}$ on adsorption was evaluated by varying $\mathrm{pH}$ from 2 to 10 using $0.1 \mathrm{M} \mathrm{HCl}$ and $0.1 \mathrm{M} \mathrm{NaOH}$ for adjustments. The contact time was varied between 10 and 60 min to study the effect of time on adsorption, and adsorbent dosage was varied from $0.2 \mathrm{~g} / 100 \mathrm{ml}$ to $1 \mathrm{~g} / 100 \mathrm{~cm}^{3}$ to know the effect of dosage. For each parameter study, the solid phase was separated using Whatman filter paper, and the residual metal concentration present in the supernatant was determined by atomic absorption spectrophotometer.

\subsection{Determination of adsorption capacity}

The amount of metal ion adsorbed onto LAC at any time, $q_{\mathrm{t}}$, was calculated from Eq. (1):

$$
q_{\mathrm{t}}=\frac{\left(c_{\mathrm{o}}-c_{\mathrm{t}}\right) V}{W}
$$

At equilibrium $q_{\mathrm{t}}=q_{\mathrm{e}}$ and $c_{\mathrm{t}}=c_{\mathrm{e}}$; therefore, the amount of adsorbed metal ion, $q_{\mathrm{e}}$, was calculated from Eq. (2):

$$
q_{\mathrm{e}}=\frac{\left(C_{\mathrm{o}}-C_{\mathrm{e}}\right) V}{W}
$$

The percentage removal of vanadium(V) from the aqueous solution was estimated using the Eq. (3):

$$
\text { removal efficiency }(\%)=\frac{\left(c_{\mathrm{O}}-C_{\mathrm{e}}\right) \cdot 100}{C_{\mathrm{o}}}
$$

where $C_{\mathrm{o}}, C_{\mathrm{t}}$, and $C_{\mathrm{e}}$ are the initial concentration, concentration at any time, and equilibrium concentration of metal ion solution $\left(\mathrm{mg} \mathrm{dm}^{-3}\right)$, respectively, $V$ is the volume of the solution $\left(\mathrm{dm}^{-3}\right)$, and $W$ is the mass of activated carbon $(\mathrm{g})$.

\subsection{Adsorption kinetics}

This study describes the vanadium $(\mathrm{V})$ uptake rate using pseudo-first order and pseudo-second order kinetic model.

Pseudo-first order model is given in Eq. (4)

$$
\log \left(q_{\mathrm{e}}-q_{\mathrm{t}}\right)=\log \left(q_{\mathrm{e}}\right)-\frac{k_{1}}{2.303} t
$$

Pseudo-second order model is represented in Eq. (5)

$$
\left(\frac{t}{q_{\mathrm{t}}}\right)=\frac{1}{k_{2} q_{\mathrm{e}}^{2}}+\frac{1}{q_{\mathrm{e}}}(t)
$$


where $q_{\mathrm{e}}$ is the amount of vanadium $(\mathrm{V})$ adsorbed at equilibrium $\left(\mathrm{mgg}^{-1}\right), q_{\mathrm{t}}$ is the amount of vanadium $(\mathrm{V})\left(\mathrm{mg} \mathrm{g}^{-1}\right)$ adsorbed at time $t(\mathrm{~min})$, and $k_{1}\left(\mathrm{~min}^{-1}\right)$ and $k_{2}(\mathrm{~g} / \mathrm{mg} / \mathrm{min})$ are the rate constants of the pseudo-first order and pseudo-second order models, respectively.

\subsection{Adsorption isotherm studies}

The relationship between the concentration of vanadi$\mathrm{um}(\mathrm{V})$ and its adsorption degree on the surface of LAC at a specific temperature was studied using different adsorption isotherm models. To assess the different isotherms, the experimental data for sorption of vanadium( $\mathrm{V})$ on LAC were fitted to the isotherm; Langmuir and Freundlich models.

The Langmuir isotherm is represented in Eq. (6):

$$
q_{\mathrm{e}}=\frac{q_{\mathrm{m}} K_{\mathrm{L}} C_{\mathrm{e}}}{1+K_{\mathrm{L}} C_{\mathrm{e}}}
$$

The linearisation of Eq. (6) leads to Eq. (7):

$$
\frac{1}{q_{\mathrm{e}}}=\frac{1}{q_{\mathrm{m}} k_{\mathrm{L}} \mathrm{C}_{\mathrm{e}}}+\frac{1}{q_{\mathrm{m}}}
$$

where $q_{\mathrm{e}}\left(\mathrm{mgg}^{-1}\right)$ is the amount of metal adsorbed at equilibrium, $q_{\mathrm{m}}\left(\mathrm{mg} \mathrm{g}^{-1}\right)$ is the maximum monolayer coverage capacity, and $K_{\mathrm{L}}\left(\mathrm{Img}^{-1}\right)$ is the Langmuir isotherm constant. The values of $q_{m}$ and $K_{L}$ were obtained from the slope and intercept of the Langmuir plot of $1 / q_{\mathrm{e}} v s .1 / c_{\mathrm{e}}$. The essential features of the Langmuir isotherm $R_{\mathrm{L}}$ are expressed in Eq. (8):

$$
R_{\mathrm{L}}=\frac{1}{1+\left(1+K_{\mathrm{L}} C_{\mathrm{o}}\right)}
$$

where $K_{L}$ is the constant related to the energy of adsorption (Langmuir constant). When $R_{\mathrm{L}}>1$, the adsorption nature is considered to be unfavourable, linear, if $R_{\mathrm{L}}=1$, favourable.

Freundlich isotherm is represented in Eq. (9):

$$
q_{\mathrm{e}}=K_{\mathrm{f}}\left(c_{\mathrm{e}}\right) 1 / n
$$

The linearisation of Eq. (9) gives Eq. (10):

$$
\ln q_{\mathrm{e}}=\ln K_{\mathrm{f}}+\frac{1}{n} \ln C_{\mathrm{e}}
$$

where $K_{\mathrm{f}}\left(\mathrm{mg} \mathrm{g}^{-1}\right)$ is the Freundlich isotherm constant, and $n$ is the adsorption intensity.

\section{Results and discussion}

\subsection{Characterisation of textile wastewater}

The physicochemical and biological characteristics of textile wastewater used in this study are presented in Table 1.
From the results, it can be seen that total dissolved solids (TDS), carbon-oxygen demand (COD), and biological oxygen demand (BOD) contributed a great deal to the perceived turbidity of textile wastewater. Heavy metal contamination occurs due to the presence of dyes and additives utilised during textile manufacturing steps, the metals listed in Table 1 cause adverse health effects. Characterisation of the wastewater was applied to evaluate the effectiveness of the $\mathrm{LAC}$ in removing vanadium $(\mathrm{V}) .^{12}$

Table 1 - Physicochemical characteristics of the textile industry wastewater

\begin{tabular}{l|l}
\hline Characteristics & Unit \\
\hline colour & yellowish green \\
\hline $\mathrm{pH}$ & 6.47 \\
\hline nickel $(\mathrm{Ni})$ & $0.015 \mathrm{mg} \mathrm{dm}^{-3}$ \\
\hline electrical conductivity (Ec) & $400.00 \mathrm{~s} \mathrm{~cm}^{-1}$ \\
\hline total dissolved solids (TDS) & $5680.90 \mathrm{mg} \mathrm{dm}^{-3}$ \\
\hline biological oxygen demand (BOD) & $543.0 \mathrm{mg} \mathrm{dm}^{-3}$ \\
\hline chemical oxygen demand (COD) & $850.00 \mathrm{mg} \mathrm{dm}^{-3}$ \\
\hline total organic carbon (TDC) & $588.09 \mathrm{mg} \mathrm{dm}^{-3}$ \\
\hline nitrate $\left(\mathrm{NO}_{3}{ }^{-\mathrm{N}}\right)$ & $1.400 \mathrm{mg} \mathrm{dm}^{-3}$ \\
\hline chloride $\left(\mathrm{Cl}{ }^{-1}\right)$ & $60.27 \mathrm{mg} \mathrm{dm}^{-3}$ \\
\hline phosphate $\left(\mathrm{PO}{ }_{4}^{3-}\right)$ & $12.50 \mathrm{mg} \mathrm{dm}^{-3}$ \\
\hline manganese $(\mathrm{Mn})$ & $38.90 \mathrm{mg} \mathrm{dm}^{-3}$ \\
\hline lead $(\mathrm{Pb})$ & $0.042 \mathrm{mg} \mathrm{dm}^{-3}$ \\
\hline copper $(\mathrm{Cu})$ & $0.016 \mathrm{mg} \mathrm{dm}^{-3}$ \\
\hline vanadium $(\mathrm{V})$ & $38.20 \mathrm{mg} \mathrm{dm}^{-3}$ \\
\hline chromium $(\mathrm{Cr})$ & $0.035 \mathrm{mg} \mathrm{dm}^{-3}$ \\
\hline zinc $(\mathrm{Zn})$ & $1.62 \mathrm{mg} \mathrm{dm}^{-3}$ \\
\hline
\end{tabular}

Fourier transform infrared spectra analysis was carried out to identify the different functional groups present in LAC. The different functional groups which are present in carbon are $\mathrm{OH}$ stretching, $\mathrm{CH}$ stretching, $\mathrm{C}=\mathrm{C}$ stretching, and $\mathrm{C}-\mathrm{O}$ stretching, which influence the adsorption characteristics of the activated carbon. FT-IR spectrum of the LAC (before adsorption) in Fig. 1 shows that the broad and intense peak at $3652.8 \mathrm{~cm}^{-1}$ was attributed to the stretching of the $\mathrm{O}-\mathrm{H}$ group due to inter-molecular and intra-molecular hydrogen bonding of polymeric compounds such as alcohols or phenols. The peak observed at $2896.1 \mathrm{~cm}^{-1}$ was associated with the stretching vibrations of the $\mathrm{CH}$ bond of methylene groups. The peaks at $1994.1 \mathrm{~cm}^{-1}$ corresponded to the $\mathrm{C}=\mathrm{C}$ stretching, which might be attributed to the presence of aromatic or olefinic bands. The intense peak at $879.7 \mathrm{~cm}^{-1}$ corresponded to $\mathrm{C}-\mathrm{O}$ stretching of alcohol or carboxylic acid as observed in Fig. 2, after the adsorption of the metal ions, the FT-IR spectra had shifted slightly after binding with metals. This was due to the participation of these functional groups in the binding of metal ions. ${ }^{13,14}$ 


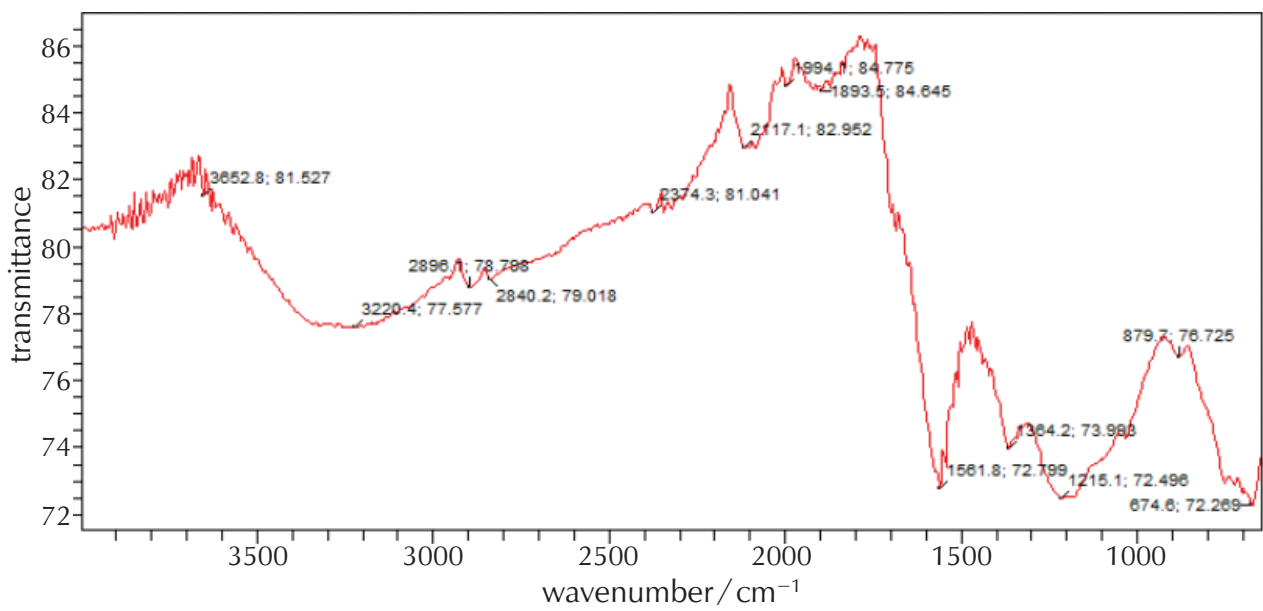

Fig. 1 - FT-IR spectrum for Luffa cylindrica activated carbon before adsorption

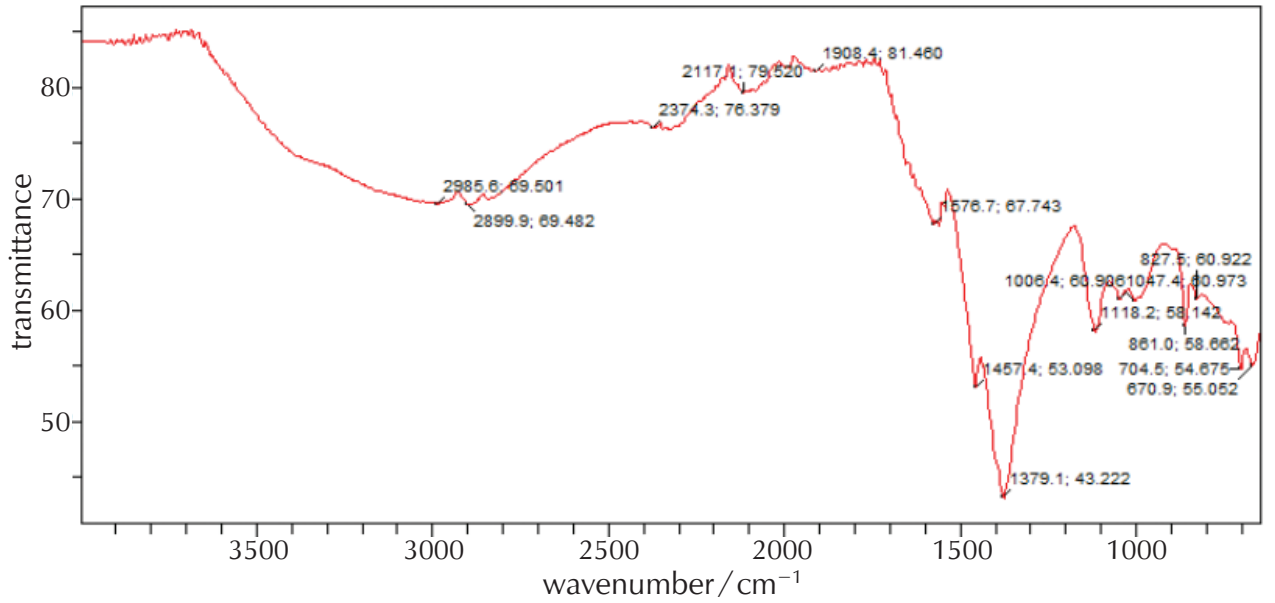

Fig. 2 - FT-IR spectrum for Luffa cylindrica activated carbon after adsorption

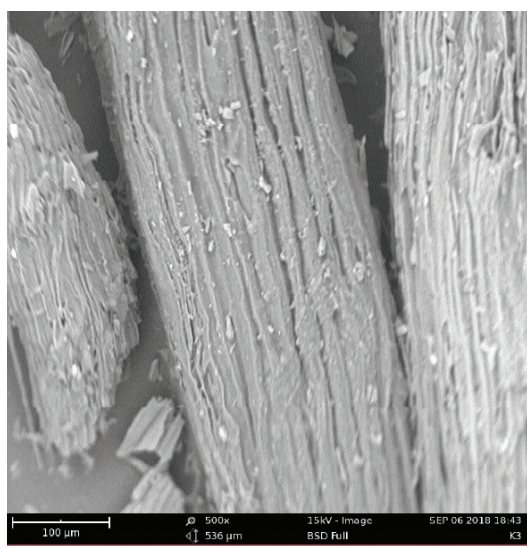

Fig. 3 - SEM image of Luffa cylindrica activated carbon before adsorption

The SEM micrograph of LAC before adsorption is shown in Fig. 3. It is observed that LAC has a smooth surface, highly porous structure with greater homogeneity, the pore structure development is a result of the LAC. Fig. 4 shows the

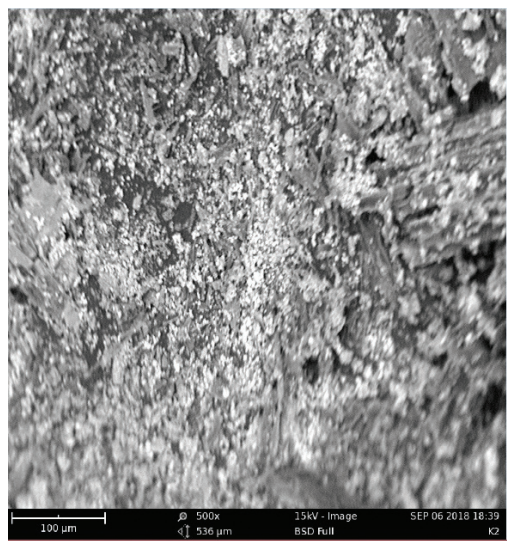

Fig. 4 - SEM image of Luffa cylindrica activated carbon after adsorption

SEM morphology of LAC after adsorption. From the figure, it is clear that a layer formed due to the adsorption of metals on the surface and occupying inside the pores of LAC. ${ }^{14}$ 


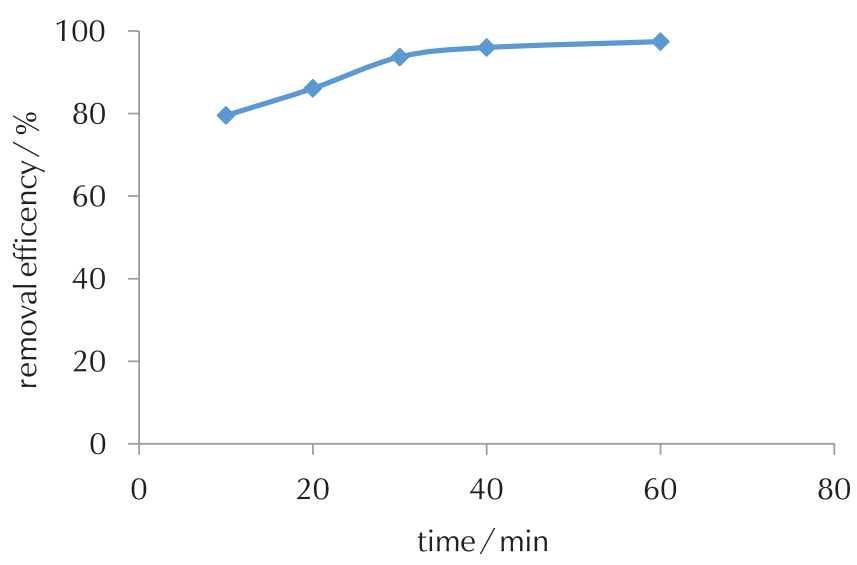

Fig. 5 - Effect of time on adsorption of vanadium(V) using Luffa cylindrica

The time dependence of adsorption of vanadium ion from textile effluent was studied by varying the contact time between 10 and $60 \mathrm{~min}$ at a constant adsorbent dosage of $0.2 \mathrm{~g}$. The adsorption rate of vanadium was observed to increase steadily as the time of contact increased with maximum adsorption observed at $60 \mathrm{~min}$ and optimum removal efficiency of $97.43 \%$, as shown in Fig. 5. At this time, little or no adsorption was observed as the adsorbent active sites had been taken up by vanadium ions establishing an equilibrium state. ${ }^{2}$

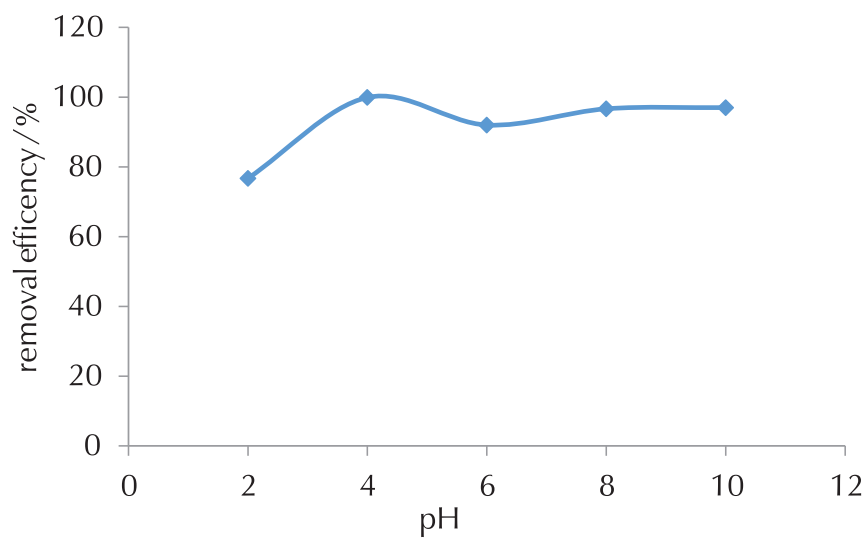

Fig. 6 - Effect of $\mathrm{pH}$ on adsorption of vanadium(V) using Luffa cylindrica

Fig. 6 indicates that LAC achieved optimal adsorptive efficiency of $99.90 \%$ at $\mathrm{pH}$ 4, the adsorption capacity of LAC increased as $\mathrm{pH}$ increased from 2 to 10 . This was because, as the $\mathrm{pH}$ increased, the surface of LAC became less positively charged, which favoured electrostatic attraction between its surface and vanadium $(\mathrm{V}) .^{15}$

Fig. 7 indicates that the percentage removal of $97.83 \%$ was obtained at an adsorbent dosage of $1.0 \mathrm{~g}$, which was attributed to the increased adsorbent surface and the availability of more adsorption sites. As the amount of adsorbent increased, the number of available adsorption sites

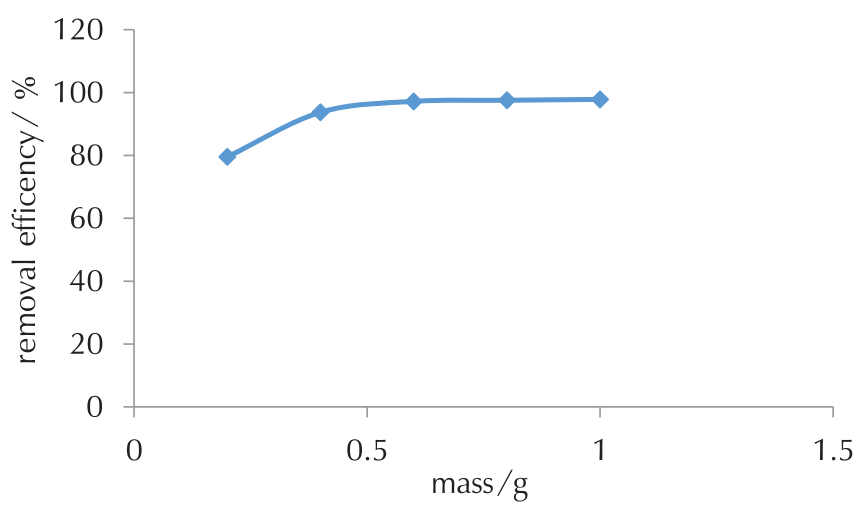

Fig. 7 - Effect of adsorbent dosage on vanadium(V) removal

increased, which directly increased the rate of adsorption. ${ }^{13,14}$

It can be deduced from Figs. 8 and 9, that the value of $q_{\mathrm{e}} / \log q_{\mathrm{e}}$ increased linearly with $c_{\mathrm{t}}$ or $\log c_{\mathrm{t}} \cdot{ }^{14}$ In Table 2, the correlation coefficient $\left(R^{2}\right)$ value for the removal of vana$\operatorname{dium}(\mathrm{V})$ in Langmuir is 0.9169 , which is close to 1 . For Freundlich isotherm, the correlation coefficient $\left(R^{2}\right)$ value for the removal of vanadium $(\mathrm{V})$ is 0.9397 , indicating that

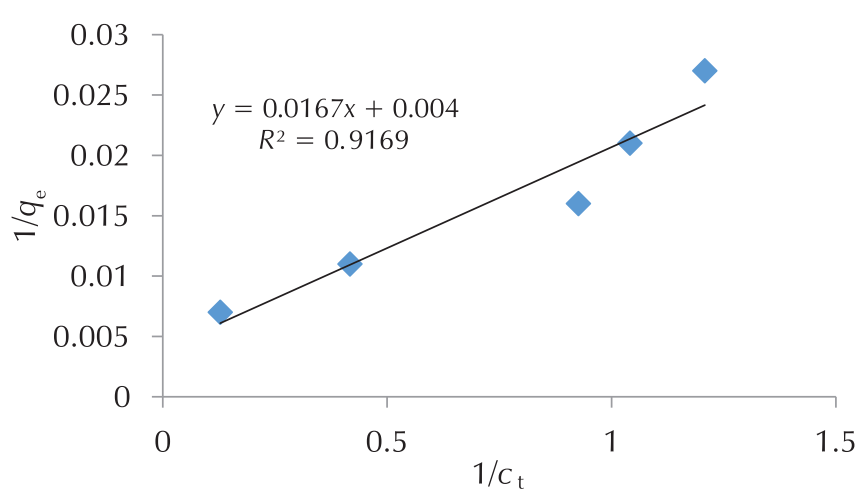

Fig. 8 - Langmuir isotherm for the adsorption of vanadium(V) removal

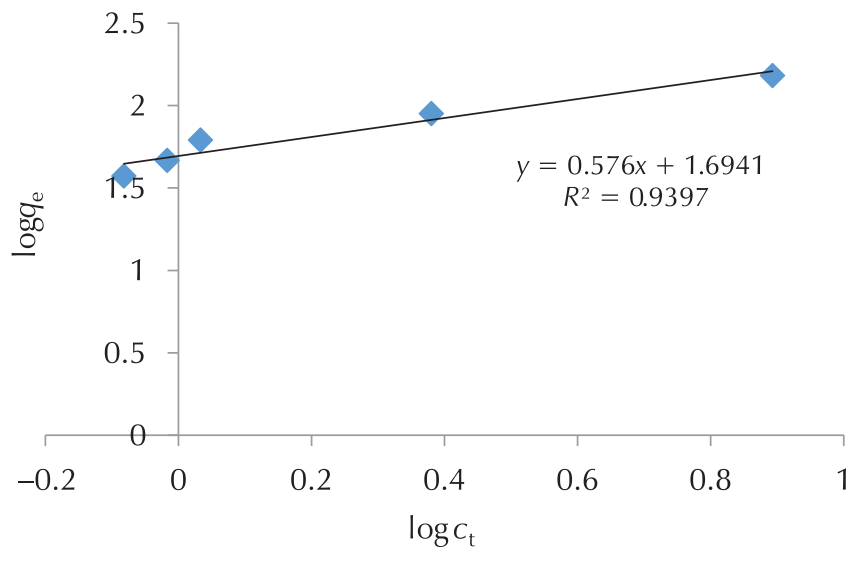

Fig. 9 - Freundlich isotherm for the adsorption of vanadium(V) removal 
Table 2 - Langmuir and Freundlich parameters for the adsorption of vanadium on LAC

\begin{tabular}{c|c|c|c|c|c|c}
\hline Models & \multicolumn{3}{|c|}{ Langmuir constants } & \multicolumn{3}{c}{ Freundlich constants } \\
\hline parameters & $q_{\mathrm{m}} / \mathrm{mgg}^{-1}$ & $b / \mathrm{mg}^{-1}$ & $R^{2}$ & $k_{\mathrm{f}} / \mathrm{mgg} \mathrm{g}^{-1}$ & $n$ & $R^{2}$ \\
\hline values & 250 & 59.88 & 0.9169 & 49.44 & 1.736 & 0.9397 \\
\hline
\end{tabular}

Table 3 - Kinetic parameters for pseudo-first and pseudo-second order for adsorption of vanadium on LAC

\begin{tabular}{c|c|c|c|c|c|c|c}
\hline Metal & \multicolumn{3}{|c|}{ Pseudo-first order } & \multicolumn{3}{c}{ Pseudo-second order } \\
\hline parameters & $q_{\text {e(exp) }} / \mathrm{mgg}^{-1}$ & $k_{1} / \mathrm{min}^{-1}$ & $q_{\text {e(cal) }} / \mathrm{mgg}^{-1}$ & $R^{2}$ & $k_{2} / \mathrm{min}^{-1}$ & $q_{\mathrm{e}(\mathrm{cal})}$ & $R^{2}$ \\
\hline values & 19.380 & 0.032 & 1.2241 & 0.8721 & 3.261 & 20.01 & 0.9224 \\
\hline
\end{tabular}

the adsorption process follows Freundlich isotherm. The value of $n$ is 1.736, hence, the adsorption process is favourable. It shows that the prepared adsorbents from LAC are extremely active in the removal of vanadium ion from aqueous solutions.

In Table 3, the $R^{2}$ value of 0.9224 for the pseudo-second order kinetic model is better than the $R^{2}$ value of 0.8721 for the pseudo-first order kinetic model. ${ }^{14,16}$

\section{Conclusion}

This study investigated the removal of vanadium(V) from the textile industry effluent using LAC. The removal of vanadium ion was found to be affected by contact time of adsorbent with the effluent, $\mathrm{pH}$ of the solution, and adsorbent dose, respectively. The optimum operating parameters were found to be at the time of $60 \mathrm{~min}$, solution $\mathrm{pH}$ of 4 , and adsorbent dose of $1.0 \mathrm{~g}$. The experimental data obtained from the adsorption experiment were modelled using Langmuir and Freundlich isotherms, and the result fitted better with Freundlich isotherm model, indicating heterogeneous surface adsorption with regression of correlation of 0.9397 as to 0.9167 given by Langmuir isotherm model. The kinetic studies were conducted, and the findings showed conformance with the pseudo-second order kinetic model.

\section{References Literatura}

1. E. Weidner, F. Ciesielczyk, Removal of hazardous oxyanions from the environment using metal-oxide-based materials, Materials (Basel) 6 (2019) 927-931, doi: https://doi. org/10.3390/ma12060927.

2. H. Gebretsadik, A. Gebrekidan, L. Demlie, Removal of heavy metals from aqueous solutions using Eucalyptus camaldulensis: An alternate low-cost adsorbent, Cogent. Chem. 6 (2020) 1-13, doi: https://doi.org/10.1080/23312009.2020 .1720892 .

3. A. Mojiri, W. Hui, A. K. Arshad, A. R. M. Ridzuan, N. H. A. Hamid, $H$. Faraji, Vanadium(V) removal from aqueous solutions using a new composite adsorbent (BAZLSC): Optimization by response surface methodology, Adv. Environ. Res. 6 (2017) 173-187, doi: https://doi.org/10.12989/aer.2017.6.3.173.

4. Q. He, S. Si, J. Zhao, H. Yan, B. Sun, Q. Cai, Removal of vanadium from vanadium-containing wastewater by amino-modified municipal sludge derived ceramic, Saudi J. Biol. Sci. 25 (2018) 1664-1669, doi: https://doi.org/10.1016/j. sjbs.2016.08.016.

5. T. Kanjilal, S. Babu, K. Biswas, C. Bhattacharjee, S. Datta, Application of mango seed integuments as bio-adsorbent in lead removal from industrial effluent, Desalin. Water Treat. 56 (2015) 984-996, doi: https://doi.org/10.1080/19443994 .2014 .950999 .

6. A. H. Gedam, R. S. Dongre, Activated carbon from Luffa cylindrica doped chitosan for mitigation of lead(II) from an aqueous solution, RSC Adv. 6 (2016) 22639-22652, doi: https://doi.org/10.1039/C5RS22580A.

7. V. Yogeshwaran, A. K. Priya, Removal of Hexavalent Chromium $\left(\mathrm{Cr}^{6+}\right)$ Using Different Natural Adsorbents A Review, J. Chromatogr. Sep. Tech. 8 (2018) 1-6, doi: https://doi. org/10.4172/2157-7064.1000392.

8. R. Sudha, K.Srinivasan, P. Premkumar, Kinetic, mechanism and equilibrium studies on removal of $\mathrm{Pb}$ (II) using Citrus limettioides peel and seed carbon, Res. Chem. Intermed. 42 (2016) 1677-1697, doi: https://doi.org/10.1007/s11164015-2111-5.

9. S. Taşar, A. Özer, A thermodynamic and kinetic evaluation of the adsorption of $\mathrm{Pb}$ (II) ions using peanut (Arachis Hypogaea) shell-based biochar from aqueous media, Pol. J. Environ. Stud. 29 (2020) 293-305, doi: https://doi.org/ 10.15244/pjoes/103027.

10. P. Saueprasea, M. Nuanjaraen, M. Chinlapa, Biosorption of Lead $\left(\mathrm{Pb}^{2+}\right)$ by Luffa cylindrica Fiber, Environ. Res. J. 4 (2010) 157-166, doi: https://doi:10.3923/erj.2010.157.166.

11. H. Demir, A. Top, D. Balköse, S. Ülkü, Dye adsorption behavior of Luffa cylindrica fibers, J. Hazard. Mater. 153 (2008) 389394, doi: https://doi.org/10.1016/j.jhazmat.2007.08.070.

12. O. I. Oboh, Modeling the effect of dosage on the biosorption of $\mathrm{Ni}^{2+}$ ions onto Luffa cylindrica, J. Mater. Sci. Appl. 4 (2018) $1-9$.

13. O. A. A. Eletta, S. I. Mustapha, O. A. Ajayi, A. T. Ahmed, Optimization of Dye Removal from Textile Wastewater using Activated Carbon from Sawdust, Nigerian J. Technol. Develop. 15 (2018) 26-32, doi: https://doi.org/10.4314/njtd.v15i1.5.

14. M. Ullah, R. Nazir, M. Khan, W. Khan, M. Shah, S. G. Afridi, A. Zada, The effective removal of heavy metals from water by activated carbon adsorbents of Albizialebbeck and Melia azedarach seed shells, Soil Water Res. 15 (2020) 30-37, doi: 
https://doi.org/10.17221/212/2018-SWR.

15. Q. Yao, Z. Xia, C. Tang, L. Zhu, T. Wang Chen, Y. Tan, Characteristics of Heavy Metal Ion Adsorption by Silty Mudstones in Coal Mine Goafs, Hindawi, Geofluids Article ID8560151 (2020) 17 pages, doi: https://doi.org/10.1155/2020/8560151.

16. B. I. Okolo, E. Awak, A. Adindu, O. Ukandu, Response surface modeling and optimization of $\mathrm{Cr}(\mathrm{VI})$ ions removal from aqueous solution using African Elemi seed (Canarium schweinfurlhi), $2^{\text {nd }}$ International Engineering Conference, IECON, 2019, Umudike J. Eng. Tehnol. (2019) 187-200, url: https://ujetmouau.net/conference_proceedings.aspx?PID $=23$.

\title{
SAŽETAK
}

\section{Adsorpcija vanadija(V) iz otpadnih voda tekstilne industrije primjenom aktivnog ugljena Luffa cylindrica}

\author{
Kenechi Nwosu-Obieogu, Goziya Dzarma, Bernard Okolo, Kelechi Akatobi i Felix Aguele
}

U ovom radu istražena je primjena aktivnog ugljena Luffa cylindrica kao jeftinog adsorbenta za uklanjanje vanadija(V) iz otpadnih voda tekstilne industrije u eksperimentu šaržne adsorpcije. Stupanj adsorpcije proučavan je za vrijeme kontakta, pH i dozu adsorbenta. Učinak pH na uklanjanje vanadija(V) proučavan je s dozom adsorbenta od 0,2 g/100 ml, vremenom kontakta od 10 min i otopinom tekstilnih otpadnih voda. Maksimalna učinkovitost uklanjanja bila je 99,90 \% pri $\mathrm{pH}=4,97,43 \%$ pri vremenu kontakta od 60 min i 97,83\% pri dozi adsorbenta od 1,0 g. Rezultati karakterizacije FTIR-a i SEM-a pokazali su da je potencijal adsorbenata u potpunosti iskorišten. U ovom su istraživanju eksperimentalni nalazi prilagođeni Langmuirovim i Freundlichovim modelima izoterme. Freundlichov model dao je bolju prilagodbu eksperimentalnim podatcima. Kinetički podatci kinetičkog modela pseudo-drugog reda dali su bolji rezultat od kinetičkog modela pseudo-prvog reda.

\section{Ključne riječi \\ Adsorpcija, Luffa cylindrica, učinkovitost, otpadne vode tekstilne industrije, okoliš}

Chemical Engineering Department Michael Okpara University of Agriculture Umuahia, Abia State

Nigerija
Izvorni znanstveni rad Prispjelo 10. lipnja 2020. Prihvaćeno 18. studenoga 2020. 